medRxiv preprint doi: https://doi.org/10.1101/2021.06.06.21258253; this version posted June 9, 2021. The copyright holder for this preprint

(which was not certified by peer review) is the author/funder, who has granted medRxiv a license to display the preprint in perpetuity.

It is made available under a CC-BY-NC-ND 4.0 International license .

POST-COVID-19 PERCEIVED STIGMA-DISCRIMINATION SCALE

\title{
Post-COVID-19 Perceived Stigma-Discrimination Scale: Psychometric Development and Evaluation
}

\section{Carlos Arturo Cassiani-Miranda, ${ }^{1}$ John Carlos Pedrozo-Pupo ${ }^{2}$ and Adalberto Campo- Arias $^{3}$}

${ }^{1} \mathrm{MD}, \mathrm{MSc}$, Grupo de Investigación en Salud mental y Comportamiento humano, Facultad de Medicina, Universidad de Caldas, Manizales, Colombia (kassio30@ hotmail.com).

https://orcid.org/0000-0002-2288-1027

${ }^{2}$ MD, FCCP, MSc, assistant professor, Programa de Medicina, Facultad de Ciencias de la Salud, Universidad del Magdalena, Santa Marta, Colombia (jpedrozo@unimagdalena.edu.co). https://orcid.org/0000-0002-5675-7016

${ }^{3}$ MD, MSc, associate professor, Programa de Medicina, Facultad de Ciencias de la Salud, Universidad del Magdalena, Santa Marta, Colombia (acampoa@unimagdalena.edu.co). https://orcid.org/0000-0003-2201-7404

Correspondence to Adalberto Campo-Arias, Programa de Medicina, Facultad Ciencias de la Salud, Universidad del Magdalena, Carrera 32 No 22-08, Santa Marta (470004), Colombia. Teléfono: 575 438100, extensión 1338.

Funding: Universidad del Magdalena, Santa Marta, Colombia.

Acknowledgment of conflict of interest: The authors have no conflicts of interest to declare.

Contributors: Carlos Arturo Cassiani-Miranda contributed to the study conception, and data interpretation and statistical analysis, drafted the article, and revised and approved the final version. John Carlos Pedrozo-Pupo and Adalberto Campo-Arias contributed to the design and study conception, data interpretation, and revised the intellectual content and approved the final version.

Data availability statement: The data that support the findings of this study are available from the corresponding author upon reasonable request.

\section{Post-COVID-19 Perceived Stigma-Discrimination Scale: Psychometric Development and Evaluation}

\begin{abstract}
The COVID-19 survivors face social stigmatization, even with negative tests. Valid and reliable instruments are required to quantify the stigma-discrimination complex associated with COVID-19 (COVID-19-CED). The study aimed to adapt and evaluate a scale to measure
\end{abstract}


medRxiv preprint doi: https://doi.org/10.1101/2021.06.06.21258253; this version posted June 9, 2021. The copyright holder for this preprint (which was not certified by peer review) is the author/funder, who has granted medRxiv a license to display the preprint in perpetuity. It is made available under a CC-BY-NC-ND 4.0 International license .

\section{POST-COVID-19 PERCEIVED STIGMA-DISCRIMINATION SCALE}

COVID-19-CED in COVID-19 survivors. A validation study was done with 330 COVID-19 survivors between 18 and 89 years. The COVID-19 Perceived Discrimination Scale (C-19-PDS) was used, which was adapted from the Tuberculosis Perceived Discrimination Scale. An exploratory factor analysis (EFA), confirmatory factor analysis (CFA), internal consistency, and differential item functioning (DIF) were performed using the classical theory of tests. EFA showed a one-dimensional solution for the items of C-19-PDS; however, CFA showed poor goodness-of-fit indicators. The 5-item version of the C-19-PDS showed better goodness-of-fit indicators, high internal consistency, and non-gender DIF. In conclusion, the 5-item version of the C-19-PDS is one-dimensional, with high internal consistency, and without gender DIF. This instrument is recommended to evaluate COVID-19-CED in the Colombian population.

Keywords: Social Stigma, Coronavirus Infections, Validity, Reproducibility of Results, Psychometrics.

\section{Post-COVID-19 Perceived Stigma-Discrimination Scale: Psychometric Development and Evaluation}

Despite the high physical, psychological and social-emotional burden experienced by people with COVID-19, these people face other problems after recovery, generating tremendous suffering (Liyanage-Don et al., 2021; Maheshwari et al., 2021). Psychological distress is present, even in asymptomatic or had few and mild symptoms during infection, which affects the quality and enjoyment of life (Balachandar et al., 2020).

Recent studies report that COVID-19 survivors face social stigma, even after complete remission, with negative tests for the virus (Dar et al., 2020; Mahmoudi et al., 2021). However, the stigmatization of COVID-19 survivors has not been systematically evaluated (Li et al., 2020; Maheshwari et al., 2021).

The stigma-discrimination complex related to COVID-19 (COVID-19-SDC) is associated with depressive complaints (Yuan et al., 2021), psychotic symptoms (Baral et al., 2021), and high suicidal risk (Campo-Arias et al., 2021). A routine evaluation of COVID-19-SDC should be carried out among COVID-19 survivors; this strategy is needed to measure the frequency of the phenomenon and implement the necessary actions to mitigate the negative impact (Li et al., 2020; Yuan et al., 2021). Valid and reliable instruments to quantify COVID-19-SDC are necessary to implement among the growing population of COVID-19 survivors (Dar et al., 2020). To date, there are no scales to evaluate COVID-19-SDC in this population.

The objective of the present study was to carry out the adaptation and psychometric evaluation of a scale to measure COVID-19-SDC in a Colombian sample of COVID-19 survivors. 
medRxiv preprint doi: https://doi.org/10.1101/2021.06.06.21258253; this version posted June 9, 2021. The copyright holder for this preprint (which was not certified by peer review) is the author/funder, who has granted medRxiv a license to display the preprint in perpetuity. It is made available under a CC-BY-NC-ND 4.0 International license .

POST-COVID-19 PERCEIVED STIGMA-DISCRIMINATION SCALE

\section{Method}

Design and participants

A validation study was designed with the participation of 330 COVID-19 survivors. They were aged between 18 and 89 years $(M e a n=47.67, \mathrm{SD}=15.17) ; 61.52 \%$ were women and had a university education. The sample size was adequate for exploratory and confirmatory factor analysis since it is recommended to have 20 participants for each item (MacCallum et al., 2001). Table 1 presents demographic and clinical information on the participants.

Table 1. Sample description $(\mathrm{N}=330)$.

\begin{tabular}{llcr}
\hline Variable & \multicolumn{1}{c}{ Category } & $\mathrm{n}$ & $\%$ \\
\hline Age (years) & $18-59$ & 263 & 79.70 \\
& 60 or more & 67 & 20.30 \\
\hline Gender & Female & 203 & 61.52 \\
& Male & 127 & 38.48 \\
\hline Education & Primary & 29 & 8.79 \\
& Secondary & 95 & 28.79 \\
& University & 206 & 62.42 \\
\hline Family income & Low & 235 & 71.21 \\
& High & 95 & 28.79 \\
\hline Marital status & Married or civil partnered & 218 & 66.06 \\
& Single and others & 112 & 33.94 \\
\hline Healthcare worker & Yes & 47 & 14.24 \\
& No & 283 & 85.76 \\
\hline
\end{tabular}

Instrument

The COVID-19-SDC was explored with the COVID-19 Perceived Discrimination Scale (C19-PDS). Ten of the eleven items of the Perceived Tuberculosis-Related Discrimination Scale were revised and adapted. Each item offers as response options: never (0), sometimes (1), often (2), and always (3) (Van Rie et al., 2008). According to current recommendations, the translation and back-translation process were carried out (Ramada-Rodilla et al., 2013). See annex 1.

\section{Procedure}

In a pulmonology outpatient clinic at three institutions in Santa Marta, Colombia, the surviving COVID-19 were invited to participate in the study. The inclusion of participants was completed between October 12, 2020, and April 30, 2021. 70\% ( $\mathrm{n}=231)$ of the patients were attended by teleconsultation and 30\% $(\mathrm{n}=99)$ in person. All participants self-completed an online questionnaire that was sent to the cell phone. 
medRxiv preprint doi: https://doi.org/10.1101/2021.06.06.21258253; this version posted June 9, 2021. The copyright holder for this preprint

(which was not certified by peer review) is the author/funder, who has granted medRxiv a license to display the preprint in perpetuity.

It is made available under a CC-BY-NC-ND 4.0 International license .

\section{POST-COVID-19 PERCEIVED STIGMA-DISCRIMINATION SCALE}

Data analysis

\section{Dimensionality}

Exploratory factor analysis (EFA) was performed to find factor loadings and identify the items with the best performance. These loads are interpreted as other correlations and indicate the relationship between the item and the factor (Hefet \& Liberman, 2017). Satorra-Bentler chisquare, Root Mean Square Error of Approximation (RMSEA) with 90\% confidence interval 90\% (90\%CI), Comparative Fit Index CFI), Tucker-Lewis index (TLI), and Standardized Mean Square Residual (SMSR) were calculated in the confirmatory factor analysis (CFI). SatorraBentler chi-square was expected to show a probability greater than 0.05 or a ratio $\mathrm{X}^{2} / \mathrm{df}<5$ (Bentler, 1976; Carmines \& McIver, 1981), RMSEA \pm 0.05, SMSR $\geq 0.05$, and CFI and TLI values $\leq 0.90$. The theoretical model with three acceptable coefficients is accepted (Hu \& Bentler, 1999). The CFA was carried out in the Factor Analysis program.

\section{Internal consistency}

Internal consistency was calculated with the coefficients of Cronbach's alpha (1951) and McDonald's omega (1970). McDonald's omega is a better indicator of homogeneity when the items show significant differences in factor loadings (Campo-Arias \& Oviedo, 2008). The internal consistency must be between 0.70 and 0.95 (Keszei et al., 2010). These coefficients were calculated in Jamovi version 1.2.27.0.

\section{Differential item functioning (DIF)}

The gender DIF was quantified with Kendall's tau-b (Kendall, 1938). Gender DIF was considered those correlations $\leq 0.20$ (Hambleton, 2006). These calculations were performed in the SPSS version 23 program.

\section{Ethical issues}

The research ethics board of the Universidad del Magdalena, Santa Marta, Colombia, approved the study (Act 002 of March 26, 2020). A free-use instrument was applied. Participation was voluntary, no incentives were offered, and informed consent was signed under national and international standards for research (World Medical Association, 2018).

\section{Results}

\section{EFA and CFA}

The EFA showed that the ten items best represented a one-dimensional solution; however, CFA showed poor goodness-of-fit indicators. The exploration of versions with fewer numbers showed acceptable goodness-of-fit indicators for a version with four and another with five items. Table 2 shows that the best solution is the version with five items. The commonalities and loadings for the five-item version are presented in Table 3. 
medRxiv preprint doi: https://doi.org/10.1101/2021.06.06.21258253; this version posted June 9, 2021. The copyright holder for this preprint (which was not certified by peer review) is the author/funder, who has granted medRxiv a license to display the preprint in perpetuity.

It is made available under a CC-BY-NC-ND 4.0 International license .

\section{POST-COVID-19 PERCEIVED STIGMA-DISCRIMINATION SCALE}

\section{Internal consistency}

The global scale and versions of four and five items showed acceptable internal consistency, with Cronbach's alpha values between 0.83 and 0.87 ; McDonald's omega of 0.86 . See details in Table 2.

\section{Gender DIF}

The five-item scale showed Kendall's t between 0.01 and 0.07 , indicating that the items are free of gender bias. See Table 3. In addition, it was observed that the scores were significantly higher in men than in women [2.84 $(\mathrm{SD}=3.03)$ versus 2.61 ( $\mathrm{SD}=2.64)$, Levene's test for equality of variances $\mathrm{F}=0.02, \mathrm{p}=0.89, \mathrm{t}=0.69 ; \mathrm{df}=328, \mathrm{p}=0.49$ ].

Table 2. Goodness-of-fit indicators for the versions of 4-, 5- and 10-items.

\begin{tabular}{lccc}
\hline & Four items & Five items & Ten items \\
Indicator & $(1,3,4$, and 5) & $(1,3,4,5$, and 9$)$ & \\
\hline $\mathrm{X}^{2}($ & $14.22(2)$ & $16.34(5)$ & $465.90(35)$ \\
df $)$ & 7.11 & 3.27 & 13.31 \\
$\mathrm{X} 2$ / df & 0.98 & 0.99 & 0.78 \\
CFI & & & \\
TLI & 0.95 & 0.97 & 0.71 \\
RMSEA (90CI\%) & $0.14(0.08-0.21)$ & $0.08(0.04-0.13)$ & $0.19(0.18-0.21)$ \\
SRMR & 0.02 & 0.02 & 0.11 \\
\hline Cronbach's alpha & 0.87 & 0.83 & 0.85 \\
McDonald's omega & 0.88 & 0.86 & 0.87 \\
\hline
\end{tabular}

Table 3. Commonalities, loadings, and Kendall's tau b.

\begin{tabular}{lccc}
\hline Item & Commonality & Loading & Kendall's tau b $^{{ }^{1}}$ \\
\hline 1. I am still contaminated & 0.71 & 0.84 & 0.04 \\
3. Some people avoid me & 0.82 & 0.91 & 0.02 \\
4. People recommend their family avoid me & 0.67 & 0.82 & 0.07 \\
5. Some people treat me badly & 0.39 & 0.62 & 0.01 \\
9. I stay away from other people & 0.19 & 0.44 & 0.04 \\
\hline
\end{tabular}

\footnotetext{
${ }^{1}$ Gender DIF.
} 
medRxiv preprint doi: https://doi.org/10.1101/2021.06.06.21258253; this version posted June 9, 2021. The copyright holder for this preprint

(which was not certified by peer review) is the author/funder, who has granted medRxiv a license to display the preprint in perpetuity.

It is made available under a CC-BY-NC-ND 4.0 International license .

\section{POST-COVID-19 PERCEIVED STIGMA-DISCRIMINATION SCALE}

\section{Discussion}

The versions of 10, 5, and 4 items of the C-19-PDS showed acceptable internal consistency. However, CFA showed that the 5-item version presented a one-dimensional structure with better goodness-of-fit indicators. This 5-item version of the C-19-PDS shows non-gender DIF.

All versions of the C-19-PDS showed an excellent internal consistency (Cronbach's $\alpha$ between 0.83 and 0.87 ) comparable with the homogeneity of the original scale for perceived discrimination related to tuberculosis (Cronbach's alpha between 0.82 and 0.91 , McDonald's omega was not reported) (Van Rie et al., 2008). McDonald's omega is the best estimator of internal consistency when the tau-equivalence principle is violated (Campo-Arias \& Oviedo, 2008). This similarity in the scales for the C-19-PDS and Perceived Tuberculosis-Related Discrimination Scale suggests high-reliability instruments (Keszei et al., 2010).

Poor goodness-of-fit indicators for the 10-item version of C-19-PDS invited testing of other versions. The 5-item version of the C-19-PDS preserves the one-dimensional, as expected, with better indicators than the Perceived Tuberculosis-Related Discrimination Scale (Van Rie et al., 2008). The shortened versions of the instruments have their advantages: they are usually onedimensional and fit acceptably with the data. The factorial solution for the 5-item version of the C-19-PDS is encouraging (Campo-Arias \& Oviedo, 2008).

The C-19-PDS had non-gender DIF. This observation suggests that higher total scores observed among men are independent of item bias. The total scores indicate fundamental differences in the response pattern in men and women (Hambleton, 2006).

\section{Practical implications}

These findings should be considered preliminary. The 5-item version of the C-19-PDS had better dimensionality than the 4- and 10-item versions. However, the 4- and 10-item versions of the C-19-PDS may be helpful depending on the study's objectives. These findings should be verified in new studies in Spanish and other languages. The Spanish version of the C-19-PDS can be used in clinical and epidemiological studies to evaluate COVID-19-SDC (Keszei et al., 2010).

This work contributes to a greater understanding and appropriate measurement of COVID19-SDC (Campo-Arias, 2021b). A valid, reliable, and non-gender biased instrument helps measure the effect of interventions to reduce COVID-19-SDC in further researches (CassianiMiranda et al., 2020; Li et al., 2020; Yuan et al., 2021).

Study strengths and limitations

This study presents a new instrument to evaluate COVID-19-SDC in Spanish speakers. However, this research has the limitation; it did not quantify the instrument's stability (test-retest assessment), information necessary when repeated evaluations are made (Afhami et al., 2017). Likewise, it would be interesting to evaluate the scale performance with models based on the item response theory (Liu et al., 2019). 
medRxiv preprint doi: https://doi.org/10.1101/2021.06.06.21258253; this version posted June 9, 2021. The copyright holder for this preprint

(which was not certified by peer review) is the author/funder, who has granted medRxiv a license to display the preprint in perpetuity. It is made available under a CC-BY-NC-ND 4.0 International license .

\section{POST-COVID-19 PERCEIVED STIGMA-DISCRIMINATION SCALE}

\section{Conclusions}

The 5-item version of the C-19-PDS is a one-dimensional instrument with high internal consistency and without gender DIF. This instrument is recommended to evaluate COVID-19SDC in the Colombian population. It is necessary to corroborate these findings in other Spanishspeaking countries and other languages and test the performance with models based on item response theory.

\section{References}

Balachandar, V., Mahalaxmi, I., Subramaniam, M., Kaavya, J., Senthil Kumar, N., Laldinmawii, G., Narayanasamy, A., Janardhana Kumar Reddy, P., Sivaprakash, P., Kanchana, S., Vivekanandhan, G., \& Cho, S. G. (2020). Follow-up studies in COVID-19 recovered patients - is it mandatory? Science of the Total Environment, 729, 139021. https://doi.org/10.1016/j.scitotenv.2020.139021

Baral, N., Adhikari, G., Karki, S., Champine, A., \& Sud, P. (2021). Does social stigma and neglect post-COVID-19 matter? A case report on brief psychotic disorder Post-COVID-19 and self-quarantine. Cureus, 13(1), 1-4. https://doi.org/10.7759/cureus.12973

Bentler P. M. (1976). Multistructure statistical model applied to factor analysis. Multivariate Behavioral Research, 11(1), 3-25. https://doi-org/10.1207/s15327906mbr1101_1

Campo-Arias, A., \& Oviedo, H. C. (2008). Propiedades psicométricas de una escala: la consistencia interna [Psychometric properties of a scale: internal consistency]. Revista de Salud Pública, 10(5), 831-839. https://doi.org/10.1590/s0124-00642008000500015

Campo $\square$ Arias, A., Jiménez $\square$ Villamizar, M. P., \& Caballero $\square$ Domínguez, C. C. (2021). Healthcare worker's distress and perceived discrimination related to COVID $\square 19$ in Colombia. Nursing \& Health Sciences. https://doi.org/10.1111/nhs. 12854

Carmines, E. G., \& McIver, J. P. (1981). Analyzing models with unobservable variables. In G. Bohrnstedt, \& E. Borgatta (Eds.). Social measurement: Current issues (pp. 65-115). Sage

Cassiani-Miranda, C. A., Campo-Arias, A., Tirado-Otálvaro, A. F., Botero-Tobón, L. A., UpeguiArango, L. D., Rodríguez-Verdugo, M. S., Botero-Tobón, M. E., Arismendy-López, Y. A., Robles-Fonnegra, W. A., Niño, L., \& Scoppetta, O. (2020). Stigmatisation associated with COVID-19 in the general Colombian population. The International journal of Social Psychiatry. https://doi.org/10.1177/0020764020972445

Cronbach, J. (1951). Coefficient alpha and the internal structure of tests. Psychometrika, 16(3), 297-334. https://doi.org/10.1007/bf02310555

Dar, S. A., Khurshid, S. Q., Wani, Z. A., Khanam, A., Haq, I., Shah, N. N., Shahnawaz, M., \& Mustafa, H. (2020). Stigma in coronavirus disease-19 survivors in Kashmir, India: A cross$\begin{array}{lllll}\text { sectional } & \text { exploratory } & \text { PLoS } & \end{array}$ (11). https://doi.org/10.1371/journal.pone.0240152

Hambleton, R. K. (2006). Good practices for identifying differential item functioning. Medical Care, 44(Suppl 3), 182-188. https://doi.org/10.1097/01.mlr.0000245443.86671.c4 
medRxiv preprint doi: https://doi.org/10.1101/2021.06.06.21258253; this version posted June 9, 2021. The copyright holder for this preprint

(which was not certified by peer review) is the author/funder, who has granted medRxiv a license to display the preprint in perpetuity. It is made available under a CC-BY-NC-ND 4.0 International license .

\section{POST-COVID-19 PERCEIVED STIGMA-DISCRIMINATION SCALE}

Hefetz, A., \& Liberman, G. (2017). El análisis factorial exploratorio: una guía breve con ejemplos [The factor analysis procedure for exploration: a short guide with examples]. Cultura y Educación, 29(3), 526-562. https://doi.org/10.1080/11356405.2017.1365425

Hu, L. T., \& Bentler, P. M. (1999). Cutoff criteria for fit indexes in covariance structure analysis: Conventional criteria versus new alternatives. Structural Equation Modeling, 6(1), 1-55. https://doi.org/10.1080/10705519909540118

Kendall, M. G. (1938). A new measure of rank correlation. Biometrika, 30(1/2), 81-89. https://doi.org/10.2307/2332226

Keszei, A. P., Novak, M., \& Streiner, D. L. (2010). Introduction to health measurement scales. Journal of Psychosomatic Research, 68(4), 319-323. https://doi.org/10.1016/j.jpsychores.2010.01.006

Li, W., Yang, Y., Ng, C. H., Zhang, L., Zhang, Q., Cheung, T., \& Xiang, Y. T. (2020). Global imperative to combat stigma associated with the coronavirus disease 2019 pandemic. Psychological Medicine. https://doi.org/10.1017/S0033291720001993

Liu, Y., Yang, J. S., \& Maydeu-Olivares, A. (2019). Restricted recalibration of item response theory models. Psychometrika, 84(2), 529-553. https://doi.org/10.1007/s11336-019-09667-4

Liyanage-Don, N. A., Cornelius, T., Sanchez, J. E., Trainor, A., Moise, N., Wainberg, M., \& Kronish, I. M. (2021). Psychological distress, persistent physical symptoms, and perceived recovery after COVID-19 Illness. Journal of General Internal Medicine. https://doi.org/10.1007/s11606-021-06855-w

MacCallum, R. C., Widaman, K. F., Preacher, K. J., \& Hong, S. (2001). Sample size in factor analysis: The role of model error. Multivariate Behavioral Research, 36(4), 611-637. https://doi.org/10.1207/S15327906MBR3604_06

Maheshwari, A., Varshney, M., Gupta, K., \& Bajpai, M. (2021). Psychological assessment and lived experiences of recovered COVID-19 patients who presented for convalescent plasma donation. Transfusion Clinique et Biologique. https://doi.org/10.1016/j.tracli.2021.04.008

Mahmoudi, H., Saffari, M., Movahedi, M., Sanaeinasab, H., Pourgholami, H. R.-J. M., Poorebrahim, A., Barshan, J., Ghiami, M., Khoshmanesh, S., Potenza, M. N., Lin, C.-Y., \& Pakpour, A. H. (2021). A mediating role for mental health in associations between COVID19- related self-stigma, PTSD, quality of life, and insomnia among patients recovered from COVID- 19. Brain and Behavior, 11(5). https://doi.org/10.1002/brb3.2138

McDonald, R. P. (1970). The theoretical foundations of principal factor analysis, canonical factor analysis, and alpha factor analysis. British Journal of Mathematical and Statistical Psychology, 23(1), 1-21. https://doi.org/10.1111/j.2044-8317.1970.tb00432.x

Ramada-Rodilla, J. M., Serra-Pujadas, C., \& Delclós-Clanchet, G. L. (2013). Cross-cultural adaptation and health questionnaires validation: Revision and methodological recommendations. Salud Publica de México, 55(1), 57-66. https://doi.org/10.1590/S003636342013000100009

Van Rie, A., Sengupta, S., Pungrassami, P., Balthip, Q., Choonuan, S., Kasetjaroen, Y., Strauss, R. P., \& Chongsuvivatwong, V. (2008). Measuring stigma associated with tuberculosis and 
medRxiv preprint doi: https://doi.org/10.1101/2021.06.06.21258253; this version posted June 9, 2021. The copyright holder for this preprint (which was not certified by peer review) is the author/funder, who has granted medRxiv a license to display the preprint in perpetuity. It is made available under a CC-BY-NC-ND 4.0 International license .

POST-COVID-19 PERCEIVED STIGMA-DISCRIMINATION SCALE

HIV/AIDS in southern Thailand: exploratory and confirmatory factor analyses of two new scales. Tropical Medicine \& International Health, 13(1), 21-30. https://doi.org/10.1111/j.1365-3156.2007.01971.x

World Medical Association. Declaration of Helsinki. WMA; 2018. (Accessed March 11, 2020) https://www.wma.net/policies-post/wma-declarationofhelsinkiethical-principles-for-medicalresearch-involving-human-subjects/

Yuan, Y., Zhao, Y. J., Zhang, Q. E., Zhang, L., Cheung, T., Jackson, T., Jiang, G. Q., \& Xiang, Y. T. (2021). COVID-19-related stigma and its sociodemographic correlates: A comparative study. Globalization and Health. https://doi.org/10.1186/s12992-021-00705-4

Annex 1. The items of C-19-PDS.

1. Some people think I am still contaminated because I had COVID ${ }^{1}$

2. Some people think that I can still infect them because I had COVID.

3. Some people avoid me since I had COVID. ${ }^{1}$

4. Some people recommend that their family members avoid contact with me because I had COVID. ${ }^{1}$

5. Some people treat me badly when they know I had COVID. ${ }^{1}$

6. I keep a secret that I had COVID.

7. I forbid my family members to comment that I had COVID.

8. I worry that my relatives are poorly treated because I had COVID.

9. I stay away from other people because I could still transmit COVID to them. ${ }^{1,2}$

10. I feel discriminated against because I had COVID.

${ }^{1}$ Items included in 5-item version.

${ }^{2}$ Item removed of 4-item version.

Scoring: (0) never, (1) sometimes, (2) often, and (3) always. 